\title{
Evaluation of Pre- or Postharvest Application of Some Minerals and Organic Agents on the Growth, Flowering and Vase Life of Rudbeckia hirta, L.
}

\author{
M. A. Hegazi ${ }^{1}$ \\ ${ }^{1}$ Department of Horticulture (Floriculture), Faculty of Agriculture, Kafr El-Sheikh University, Kafr El-Sheikh, \\ Egypt
}

Correspondence: M. A. Hegazi, Department of Horticulture (Floriculture), Faculty of Agriculture, Kafr El-Sheikh University, Kafr El-Sheikh, Egypt. Tel: 20-106-603-3059. E-mail: abohegazi@yahoo.com

Received: May 16, 2016

Accepted: July 15, 2016

Online Published: August 15, 2016

doi:10.5539/jas.v8n9p226

URL: http://dx.doi.org/10.5539/jas.v8n9p226

\begin{abstract}
The experiments were carried out during 2014 and 2015 summer seasons at the greenhouses of the Experimental Farm of Faculty of Agriculture, Kafr El-Sheikh University. The experiments were conducted in two phases: First one (pre-harvest): Rudbeckia hirta seedlings were transplanted during the first week of May to $30 \mathrm{~cm}$ diameter plastic pots filled with a soil mixture of clay and sand (1:1, v:v). Pots were divided in two equal groups, the first one, plants were foliar sprayed with one of the following:- Distilled water for the control treatment, $\mathrm{CaCl}_{2}(125$, $\left.250,375 \mathrm{mg} \cdot \mathrm{L}^{-1}\right), \mathrm{NiSO}_{4}\left(30,45,60 \mathrm{mg} \cdot \mathrm{L}^{-1}\right), \mathrm{CoCl}_{2}\left(50,75,100 \mathrm{mg} \cdot \mathrm{L}^{-1}\right), \mathrm{K}_{2} \mathrm{SiO}_{3}\left(100,150,200 \mathrm{mg} \cdot \mathrm{L}^{-1}\right)$ and SA $\left(100,150,200 \mathrm{mg} \cdot \mathrm{L}^{-1}\right)$ at $60,45,30$ and 15 days before harvest. The second group was without pre-harvest application assay (untreated plants).

Second phase (postharvest) was conducted in two different methods as follows: First method, flower stems resulted from each pre-harvest treatment were preserved in $250 \mathrm{~mL}$ graduated test tube filled with $200 \mathrm{~mL}$ of standard holding solution consists of sucrose $(4 \%)+8$-Hydroxyquinoline citrate $\left(250 \mathrm{mg} \cdot \mathrm{L}^{-1}\right)$. The second method, flower stems resulted from plants without pre-harvest application preserved in holding solution consists of a constant sucrose $(4 \%)$ and 8 -Hydroxyquinoline citrate $\left(250 \mathrm{mg} \cdot \mathrm{L}^{-1}\right)$ beside one of the following additives: Distilled water for the control treatment, $\mathrm{CaCl}_{2}\left(125,250,375 \mathrm{mg} \cdot \mathrm{L}^{-1}\right), \mathrm{NiSO}_{4}\left(30,45,60 \mathrm{mg} \cdot \mathrm{L}^{-1}\right), \mathrm{CoCl}_{2}(50,75$, $\left.100 \mathrm{mg} \cdot \mathrm{L}^{-1}\right), \mathrm{K}_{2} \mathrm{SiO}_{3}\left(100,150,200 \mathrm{mg} \cdot \mathrm{L}^{-1}\right)$ and Salicylic acid $\left(100,150,200 \mathrm{mg} \cdot \mathrm{L}^{-1}\right)$. Results showed that, pre harvest spraying plants with higher levels of $\mathrm{K}_{2} \mathrm{SiO}_{3}$ or $\mathrm{CaCl}_{2}$ recorded the highest values for all plant vegetation characters. $\mathrm{K}_{2} \mathrm{SiO}_{3}$ followed by $\mathrm{SA}$ excelled on others in most flowering aspects. At the post harvest stage, SA, $\mathrm{K}_{2} \mathrm{SiO}_{3}$ and $\mathrm{CaCl}_{2}$ exchanged the excellence between them for most vase life measurements. Flowers resulted from plants that preharvest treated was better than those that did not preharvest treated.
\end{abstract}

Keywords: Rudbeckia hirta, vase life, pre and postharvest applications, minerals or organic agents

\section{Introduction}

Maintaining cut flowers quality and extending vase life are considered important and practical for having acceptable products. Rudbeckia hirta L. (Indian Summer variety) commonly called black-eyed Susan, is a member of the Asteraceae family and native to the Eastern and Central North America. It is important in the horticulture industry due to its golden orange that characterized by flowers long postharvest life, tolerance to cold storage, suitable for wholesale marketing furthermore, adaptable and attractive native plant that requires little maintenance (Fulcher et al., 2003). Rudbeckia is a short-lived perennials or annual, obligate long-day plant with a critical photoperiod of 13-14 hours, starts blooming in mid-summer and continues to fall. These late summer workhorses in the garden are wonderful massed in borders, staged in small groups throughout the bed or in containers. Rudbeckia roots and flowers sometimes used in place of Echinacea when it was not available as teas or compresses to treat snakebites, worms, earaches, indigestion, burns and sores (Gilman \& Howe, 1999).

Vase life of cut flowers is mainly affected by two main factors, namely ethylene which accelerates the senescence of many flowers and microorganisms which cause vascular blockage and thus reduce the vase life of cut flowers (Van Doorn et al., 1994; Zencirkiran, 2005, 2010). 
Calcium has been known as one of the most important components to award resistance and strength of cell walls. It promotes postharvest life of flowering plants as well as accelerates bud opening and delays the senescence (Fergusen, 1984; Michalczuk et al., 1989). Calcium treatment causes a delayed protein and phospholipids reduction off the cell membrane and increases ATP activity in petals (Malakooti, 2001). Calcium can help to ameliorate the adverse effect of salinity on plants. It was reported to maintain membrane integrity and regulate ion transport and is essential for $\mathrm{K} / \mathrm{Na}$ and $\mathrm{Ca} / \mathrm{Na}$ selectivity (Renault, 2005). Silicon is not consider as an essential element for the plant growth and development, but it possesses beneficial impact on overall aspects of plant life such as suppressing biotic and abiotc stresses. Accumulation of $\mathrm{Si}$ in the epidermal tissue of the plant is the main mechanism which provides defense against insect and fungal attacks. It might make complex with organic compounds in the cell walls of epidermal cells, therefore increasing their resistance to degrading enzymes (Snyder et al., 2007).

$\mathrm{Ni}$ is the most recently element which is classified as essential for plant life cycle (Brown et al., 1987). Ni has an inhibitory effect on the enzyme responsible for production of ethylene (ACC oxidase) by forming an enzyme metal complex (Smith \& Woodburn, 1984). Inhibitory effect of Ni on ethylene makes this element a good choice for improving the postharvest life of the horticultural crops especially cut flowers. Lower total soluble carbohydrates is an indication on the delay in flowers senesce. On the other hand the nitrogen cycle within plants can be affected by Ni (Bai et al., 2006) and this element have beneficial influence on rigidity of protein structures which might increase the total resistance of plants against senescence (Wood \& Reilly, 2007). Cobalt can impede the production and accumulation of ethylene which feature an account for vase life augmentation. It caused a delaying in senescence by arresting the decline of chlorophyll and protein of lettuce (Tosh et al., 1979). An increment in vase life of marigold, chrysanthemum, rose and maidenhair fern has been reported after Co application. Also this element has a long-lasting effect in preserving apple as the fruits are kept fresh by Co application after ripening (Talukder \& Sharma, 2007).

Salicylic acid is an endogenous growth regulator of phenolic nature, which participates in the regulation of plant physiological processes. It is plays a role of natural inductor of thermo genesis in Arum lily, induces flowering in a range of plants, controls ion uptake by roots stomatal conductivity and photosynthetic rate and considered to be a potent plant hormone because of its diverse regulatory roles in plant metabolism (Raskin, 1992; Popova et al., 1997; Khan et al., 2003). There are experimental data indicating participation of Salicylic acid in signal regulation of gene expression in the course of leaf senescence in Arabidopsis (Morris et al., 2000). Acetyl salicylic acid has been reported to inhibit ethylene production (Leslie \& Romani, 1988; Srivastava \& Dwivedi, 2000).

This study aims to conclude the best pre or postharvest treatments for improving the keeping quality of Rudbeckia hirta cut flowers.

\section{Materials and Methods}

\subsection{Plant Material}

The experiments were carried out during 2014 and 2015 summer seasons at the greenhouses of the Experimental Farm of Faculty of Agriculture, Kafr El-Sheikh University as experiments were conducted in two phases:

\subsubsection{First Phase (Pre-Harvest Treatments)}

During the second week of March of each season, Rudbeckia hirta seeds were sown in trays (82 cells) and seedlings were transplanted (one plant in each pot) during the first week of May to $30 \mathrm{~cm}$ diameter plastic pots filled with a soil mixture of clay and sand (1:1, v:v). The experimental layout was Randomized complete block design with three replicates (three pots in each replicate). Pots were divided in two equal groups.

i). First group: Plants were foliar sprayed with: Distilled water for the control treatment, $\mathrm{CaCl}_{2}(125,250,375$ $\left.\mathrm{mg} \cdot \mathrm{L}^{-1}\right), \mathrm{NiSO}_{4}\left(30,45,60 \mathrm{mg} \cdot \mathrm{L}^{-1}\right), \mathrm{CoCl}_{2}\left(50,75,100 \mathrm{mg} \cdot \mathrm{L}^{-1}\right), \mathrm{K}_{2} \mathrm{SiO}_{3}\left(100,150,200 \mathrm{mg} \cdot \mathrm{L}^{-1}\right)$ and Salicylic acid $\left(100,150,200 \mathrm{mg} \cdot \mathrm{L}^{-1}\right)$. Each plant was sprayed to run-off stage (approximately $25 \mathrm{~mL}$ per each plant) using hand atomizer to assure complete coverage of foliage and Tween- 20 was used as a surfactant with these treatments at the rate of $0.01 \%$. The application frequency was four times at $60,45,30$ and 15 days before harvest).

ii). Second group: Plants without pre-harvest application assay (untreated plants).

All cultural practices, irrigation, fertilization etc. were carried out as recommended in the Rudbeckia hirta plants production program. At the end of the first phase (last week of June), the following vegetation parameter were recorded: Plant height, plant width (measuring the maximum width of the plant, then taking another width measurement perpendicular to the initial measurement, and averaging the two numbers), stems number and 
shoots fresh and dry weights in addition, total green color was measured in SPAD values using a portable chlorophyll meter (Minolta SPAD-502, Japan). Furthermore, some flowering measurements were recorded like transplanting-flowering period, flowers number, flower diameter, and flower fresh weight (initial flower fresh weight).

\subsubsection{Second Phase (Postharvest Treatments)}

Flowers were harvested in the morning at the anthesis stage and immediately taken within 1 hrs to the Horticulture Laboratory of Faculty of Agriculture. Flowers were selected for uniformity in terms of development and pre-cooling was performed by placing flowers stem in ice cold water for $3 \mathrm{hrs}$ to remove the field heat (Capdeville et al., 2005). Postharvest phase was conducted in two different methods as follows:

i). First one: Three cut flower stems resulted from each pre-harvest treatment were slantly re-cut to $25 \mathrm{~cm}$ under water and the leaves were eliminated till nod 5, then puted in $250 \mathrm{~mL}$ graduated test tube filled with $200 \mathrm{~mL}$ of standard holding solution consists of sucrose $(4 \%)+8$-Hydroxyquinoline citrate $\left(250 \mathrm{mg} \cdot \mathrm{L}^{-1}\right)$ with $10 \mathrm{~cm}$ depth and was considered as a replication.

ii). Second method: Cut flower stems resulted from the second group (plants without pre-harvest application) have been processed in the corresponding technique before placing in $250 \mathrm{~mL}$ graduated test tube filled with 200 $\mathrm{mL}$ holding solution consists of a constant sucrose $(4 \%)$ and 8 -Hydroxyquinoline citrate $\left(250 \mathrm{mg} \cdot \mathrm{L}^{-1}\right)$ beside one of the following additives: Distilled water for the control treatment, $\mathrm{CaCl}_{2}\left(125,250,375 \mathrm{mg} \cdot \mathrm{L}^{-1}\right), \mathrm{NiSO}_{4}(30,45$, $\left.60 \mathrm{mg} \cdot \mathrm{L}^{-1}\right), \mathrm{CoCl}_{2}\left(50,75,100 \mathrm{mg} \cdot \mathrm{L}^{-1}\right), \mathrm{K}_{2} \mathrm{SiO}_{3}\left(100,150,200 \mathrm{mg} \cdot \mathrm{L}^{-1}\right)$ and Salicylic acid $\left(100,150,200 \mathrm{mg} \cdot \mathrm{L}^{-1}\right)$.

The test tube mouths were covered with a sheet of Aluminum foil to minimize evaporation and contamination. The flowers were kept in a postharvest laboratory at room temperature $\left(25 \pm 4{ }^{\circ} \mathrm{C}\right)$, relative humidity of $65 \pm 5 \%$ and $24 \mathrm{hrs}$ light with energy saver, cool light lamps to complete vase life and the following measurements were recorded:

\subsection{Relative Fresh Weight Changes (RFW)}

Fresh weight of the flowers was determined just before the immersion of the flowers into the solutions and repeated another three times at 6,12 and 18 days of the immersion. The fresh weight of each flower was expressed relative to the initial weight to represent the water status of the flower (Joyce \& Jones, 1992).

$$
R F W=(\text { Final weight/initial weight }) \times 100
$$

\subsection{Vase Life}

Vase life was calculated as the days number between harvest time and that of experiment termination which was recorded when stem collapsed or the petals began to turn brown (Bleeksma \& Van Doorn, 2003).

\subsection{Solution Uptake(S)}

Solution uptake was determined using a balance by weighing each vase containing its solution without flowers and correcting the probably evaporation from the evapo-control vase (vase which did not contain any flowers and located between the vases that contained flowers) by subtracting the average of evaporation data from solution uptake every 3 days. Vase solution uptake was calculated using the following formula:

$$
\text { Solution uptake }=[S(t-3)-\text { St/initial fresh weight }] \times 100
$$

Where, $S t=$ Solution weight (ml/3 flowers) at 3, 6, 9 and 12 days (Chamani et al., 2005).

\subsection{Protein Content}

Protein concentration of the supernatant was estimated using the method of Bradford (1976). The absorbance of blue color was read at $595 \mathrm{~nm}$ using uv-visible spectrophotometer and amount of protein was quantified by using a standard curve and results were expressed as $\mathrm{mg}$ protein per $\mathrm{g}$ fresh weight of petals.

\subsection{Anthocyanin Contents}

Anthocyanin contents in fresh petal samples were determined calorimetrically according to Husia et al. (1965).

\subsection{Soluble Carbohydrates Contents}

Approximately $0.25 \mathrm{~g}$ dry grinds of flowers and leaves materials were fixed in ethanol (95\%), then macerated and centrifuged (3500 X, $10 \mathrm{~min})$. The supernatants were pooled and used for estimation of carbohydrate contents using the method of Pakqain and Lechacer (1976).

\subsection{Total Carotenoids}

Total carotenoids were determined in fresh petals samples according to Nornai (1982). 


\subsection{Statistical Analysis}

The experiments were conducted twice in a completely randomized block design with 3 replications and the obtained data were subjected to statistical analysis of variance (ANOVA). Both ANOVA were computed using MSTAT-C (MSTAT Development Team, 1989) and the mean separations were carried out according to Duncan's multiple range test (Duncan, 1955) and significance was determined at $\mathrm{p}<0.05$.

\section{Results and Discussions}

\subsection{Pre Harvest Stage}

\subsubsection{Effect of Pre Harvest Treatments on Rudbeckia hirta, L. Vegetation}

It was noticed that, control treatment (plants sprayed with distilled water) recorded the absolutely lowest values for all vegetation measurements (Table, 1). The tallest plants resulted from the treatments of $\mathrm{CaCl}_{2}\left(375 \mathrm{mg} \cdot \mathrm{L}^{-1}\right)$ and Salicylic acid $\left(200 \mathrm{mg} \cdot \mathrm{L}^{-1}\right)$, followed by $\mathrm{NiSO}_{4}\left(60 \mathrm{mg} \cdot \mathrm{L}^{-1}\right)$ and $\mathrm{CoCl}_{2}\left(75 \mathrm{mg} \cdot \mathrm{L}^{-1}\right)$, respectively. $\mathrm{K}_{2} \mathrm{SiO}_{3}$ at $200 \mathrm{mg} \cdot \mathrm{L}^{-1}$ recorded the highest values for plant width, stems number and shoots fresh and dry weights. In the second rank lies the treatments $\mathrm{CaCl}_{2}\left(375 \mathrm{mg} \cdot \mathrm{L}^{-1}\right)$ and Salicylic acid $\left(200 \mathrm{mg} \cdot \mathrm{L}^{-1}\right)$. The other treatments gave an intermediate values for most studied growth characters. As for total green color, $\mathrm{K}_{2} \mathrm{SiO}_{3}$ at $200 \mathrm{mg} \cdot \mathrm{L}^{-1}, \mathrm{CaCl}_{2}$ (375 $\left.\mathrm{mg} \cdot \mathrm{L}^{-1}\right)$, Salicylic acid $\left(200 \mathrm{mg} \cdot \mathrm{L}^{-1}\right)$ then $\mathrm{NiSO}_{4}\left(60 \mathrm{mg} \cdot \mathrm{L}^{-1}\right)$ recorded the best results compared to other treatments or control. Numerous laboratory, greenhouse and field experiments have shown benefits of $\mathrm{Si}$ application on different aspects of plant growth (Snyder et al., 2007). Cobalt application has no effect on chlorophyll contents of Argyranthemum cut flowers (Kazemi, 2012).

Table 1. Effect of pre harvest treatments on some growth characters of Rudbeckia hirta, L. (Mean of both seasons)

\begin{tabular}{|c|c|c|c|c|c|c|c|}
\hline Treatments & $\begin{array}{l}\text { Level } \\
\left(\mathrm{mg} \cdot \mathrm{L}^{-1}\right)\end{array}$ & $\begin{array}{l}\text { Plant height } \\
\text { (cm) }\end{array}$ & $\begin{array}{l}\text { Plant width } \\
(\mathrm{cm})\end{array}$ & $\begin{array}{l}\text { Stems } \\
\text { number }\end{array}$ & $\begin{array}{l}\text { Shoots fresh } \\
\text { weight }(\mathrm{g})\end{array}$ & $\begin{array}{l}\text { Shoots dry } \\
\text { weight (g) }\end{array}$ & $\begin{array}{l}\text { Total green } \\
\text { color (SPAD) }\end{array}$ \\
\hline Control & - & 48.350 & $24.57 \mathrm{n}$ & $6.58 \mathrm{p}$ & $21.42 p$ & $12.08 \mathrm{p}$ & $36.45 \mathrm{p}$ \\
\hline \multirow[t]{3}{*}{$\mathrm{CaCl}_{2}$} & 125 & $62.60 \mathrm{~h}$ & $32.70 \mathrm{k}$ & $9.13 \mathrm{k}$ & $26.83 \mathrm{~m}$ & $16.20 \mathrm{~m}$ & 38.920 \\
\hline & 250 & $67.05 \mathrm{~d}$ & $37.18 \mathrm{e}$ & $11.43 \mathrm{f}$ & $30.52 \mathrm{~g}$ & $18.17 \mathrm{i}$ & $42.55 \mathrm{k}$ \\
\hline & 375 & $76.09 \mathrm{a}$ & $41.23 b$ & $12.27 \mathrm{~d}$ & $34.09 \mathrm{~b}$ & $20.15 \mathrm{c}$ & $47.34 \mathrm{c}$ \\
\hline \multirow[t]{3}{*}{$\mathrm{NiSO}_{4}$} & 30 & $50.61 \mathrm{n}$ & 30.421 & $8.07 \mathrm{n}$ & $24.91 \mathrm{n}$ & $15.69 \mathrm{n}$ & 42.501 \\
\hline & 45 & $55.04 \mathrm{~m}$ & $35.07 \mathrm{~g}$ & $9.26 \mathrm{j}$ & $28.20 \mathrm{j}$ & $17.94 \mathrm{j}$ & $42.98 \mathrm{i}$ \\
\hline & 60 & $65.77 \mathrm{e}$ & $38.63 \mathrm{~d}$ & $11.60 \mathrm{e}$ & $31.09 \mathrm{f}$ & $19.04 \mathrm{~g}$ & $44.23 \mathrm{e}$ \\
\hline \multirow[t]{3}{*}{$\mathrm{CoCl}_{2}$} & 50 & $58.58 \mathrm{j}$ & $25.95 \mathrm{~m}$ & 7.790 & $23.84 \mathrm{o}$ & $14.77 \mathrm{o}$ & $42.16 \mathrm{~m}$ \\
\hline & 75 & $65.03 \mathrm{f}$ & $33.76 \mathrm{j}$ & 8.641 & $27.91 \mathrm{k}$ & $18.77 \mathrm{~h}$ & $44.10 \mathrm{~g}$ \\
\hline & 100 & $63.12 \mathrm{~g}$ & $34.22 \mathrm{i}$ & $9.75 \mathrm{i}$ & $30.12 \mathrm{~h}$ & 16.891 & $43.58 \mathrm{~h}$ \\
\hline \multirow[t]{3}{*}{$\mathrm{K}_{2} \mathrm{SiO}_{3}$} & 100 & 56,201 & $37.11 \mathrm{e}$ & $10.21 \mathrm{~h}$ & $33.18 \mathrm{~d}$ & $19.50 \mathrm{e}$ & $41.04 \mathrm{n}$ \\
\hline & 150 & $57.22 \mathrm{k}$ & $40.87 \mathrm{c}$ & $12.75 b$ & $34.07 \mathrm{c}$ & $19.57 \mathrm{~d}$ & $47.61 \mathrm{~b}$ \\
\hline & 200 & $61.32 \mathrm{i}$ & $45.70 \mathrm{a}$ & $14.94 \mathrm{a}$ & $37.88 \mathrm{a}$ & $22.35 \mathrm{a}$ & $48.22 \mathrm{a}$ \\
\hline \multirow[t]{3}{*}{ SA } & 100 & $65.69 \mathrm{e}$ & $25.03 \mathrm{~m}$ & $8.31 \mathrm{~m}$ & 27.611 & $17.39 \mathrm{k}$ & $42.68 \mathrm{j}$ \\
\hline & 150 & $69.84 c$ & $35.20 \mathrm{~h}$ & $10.75 \mathrm{~g}$ & $29.83 \mathrm{i}$ & $19.11 \mathrm{f}$ & $44.12 \mathrm{f}$ \\
\hline & 200 & $71.03 b$ & $36.55 \mathrm{f}$ & $12.33 \mathrm{c}$ & $32.80 \mathrm{e}$ & $20.62 b$ & $46.77 \mathrm{~d}$ \\
\hline
\end{tabular}

Note. Means within a column having the same letters are not significantly different in Duncan's Multiple Range Test.

\subsubsection{Effect of Pre Harvest Treatments on Rudbeckia hirta, L. Flowering}

Data in Table 2 showed that, control treatments was too little too late in flowering date compared to all other treatments. The shortest transplanting-flowering period resulted from $\mathrm{CoCl}_{2}\left(100 \mathrm{mg} \cdot \mathrm{L}^{-1}\right), \mathrm{CaCl}_{2}\left(375 \mathrm{mg} \cdot \mathrm{L}^{-1}\right)$ and $\mathrm{K}_{2} \mathrm{SiO}_{3}\left(200 \mathrm{mg} \cdot \mathrm{L}^{-1}\right)$ treatments followed by Salicylic acid $\left(200 \mathrm{mg} \cdot \mathrm{L}^{-1}\right)$ and $\mathrm{NiSO}_{4}\left(60 \mathrm{mg} \cdot \mathrm{L}^{-1}\right)$, respectively. the other treatments recorded intermediate period to bloom.

As for flowers number, data illuminate that flowers number gradually declined as the used substances concentration increase. in contrast, both flower diameter and initial flower fresh weight exhibited a gradual increase whenever each substance level increase. These results are in harmony with those reported by Jamshidi et al. (2012) who pointed out that Salicylic acid significantly increased flower diameter of Gerbera plants. 
Table 2. Effect of pre harvest treatments on some flowering mesurments of Rudbeckia hirta, L. (Mean of both seasons)

\begin{tabular}{|c|c|c|c|c|c|}
\hline Treatments & $\begin{array}{l}\text { Level } \\
\left(\mathrm{mg} \cdot \mathrm{L}^{-1}\right)\end{array}$ & $\begin{array}{l}\text { Transplanting-Flowering } \\
\text { (day) }\end{array}$ & Flowers numer & $\begin{array}{l}\text { Flower diameter } \\
(\mathrm{mm})\end{array}$ & $\begin{array}{l}\text { Initial flower fresh weight } \\
(\mathrm{g})\end{array}$ \\
\hline Control & - & $115.03 \mathrm{a}$ & $18.04 \mathrm{~m}$ & $56.8 \mathrm{o}$ & $12.74 p$ \\
\hline \multirow[t]{3}{*}{$\mathrm{CaCl}_{2}$} & 125 & $83.61 \mathrm{~h}$ & $23.55 \mathrm{i}$ & $86.5 \mathrm{f}$ & $15.33 \mathrm{~m}$ \\
\hline & 250 & $75.83 \mathrm{j}$ & $20.71 \mathrm{k}$ & $87.9 \mathrm{e}$ & $16.82 \mathrm{e}$ \\
\hline & 375 & $67.60 \mathrm{~m}$ & $21.10 \mathrm{j}$ & $90.4 d$ & $17.06 \mathrm{~b}$ \\
\hline \multirow[t]{3}{*}{$\mathrm{NiSO}_{4}$} & 30 & $100.44 \mathrm{c}$ & $30.51 \mathrm{~d}$ & 68.81 & $14.69 \mathrm{o}$ \\
\hline & 45 & $95.37 \mathrm{~g}$ & $27.08 \mathrm{~g}$ & $72.0 \mathrm{j}$ & $15.75 \mathrm{j}$ \\
\hline & 60 & $97.04 \mathrm{e}$ & $26.43 \mathrm{~h}$ & $79.5 \mathrm{~h}$ & $16.20 \mathrm{~h}$ \\
\hline \multirow[t]{3}{*}{$\mathrm{CoCl}_{2}$} & 50 & $67.50 \mathrm{n}$ & $34.10 \mathrm{~b}$ & $71.1 \mathrm{k}$ & $14.94 n$ \\
\hline & 75 & $64.77 \mathrm{o}$ & $27.41 \mathrm{f}$ & $78.9 \mathrm{i}$ & 15.381 \\
\hline & 100 & $60.34 p$ & $27.06 \mathrm{~g}$ & $81.0 \mathrm{~g}$ & $15.82 \mathrm{i}$ \\
\hline \multirow[t]{3}{*}{$\mathrm{K}_{2} \mathrm{SiO}_{3}$} & 100 & $81.22 \mathrm{i}$ & 19.111 & $93.6 \mathrm{c}$ & $16.47 \mathrm{~g}$ \\
\hline & 150 & $74.12 \mathrm{k}$ & $17.45 n$ & $98.4 \mathrm{~b}$ & $17.00 \mathrm{c}$ \\
\hline & 200 & 70.881 & $15.32 \mathrm{o}$ & $102.6 \mathrm{a}$ & $17.37 \mathrm{a}$ \\
\hline \multirow[t]{3}{*}{ SA } & 100 & $107.26 \mathrm{~b}$ & $28.22 \mathrm{e}$ & $59.2 \mathrm{n}$ & $15.70 \mathrm{k}$ \\
\hline & 150 & $98.50 \mathrm{~d}$ & $37.41 \mathrm{a}$ & $64.7 \mathrm{~m}$ & $16.72 \mathrm{f}$ \\
\hline & 200 & $95.78 \mathrm{f}$ & $33.18 \mathrm{c}$ & 68.91 & $16.93 \mathrm{~d}$ \\
\hline
\end{tabular}

Note. Means within a column having the same letters are not significantly different in Duncan's Multiple Range Test.

\subsection{Postharvest Stage}

\subsubsection{Effect of Pre and Postharvest Treatments on Relative Flower Fresh Weight Changes}

It was observed that, all pre or post treatments exceeded control in relative flower fresh weight all (Table 3). Flower relative fresh weight gradually increased by the time till the twelfth day then begin to decrease as the flower vase life increased. In general, Pre harvest treatments showed a highest relative flower fresh weights than that postharvest treated one. The highest levels of the treatments of $\mathrm{CaCl}_{2}, \mathrm{NiSO}_{4}$ and $\mathrm{K}_{2} \mathrm{SiO}_{3}$, followed by Salicylic acid and $\mathrm{CoCl}_{2}$ recorded the highest relative flower fresh weight changes over all other pre harvest treatments. Whereas, in case of postharvest treatments, it was found that the highest levels of $\mathrm{NiSO}_{4}$ and $\mathrm{K}_{2} \mathrm{SiO}_{3}$ surpassed all other treatments during all vase life period. There are an insignificant differences among the second and the third readings of relative flower fresh weight changes. Ichimura et al. (2001) found that addition calcium chloride increases fresh weight and delays weight loss. Also, Mortazavi et al. (2007) reported that the addition of calcium to vase roses increased the relative water content in petals, the water flow in the stalk segments tended to be greater with the $\mathrm{CaCl}_{2}(10 \mathrm{mM})$ treatment at the beginning of the experiment. This suggests a greater effectiveness of this cation as a water stimulant. Likewise, Cortes et al. (2011) stated that, addition $\mathrm{CaCl}_{2}$ to the preservative solution recorded the greatest total fresh weight for cut rose flowers head. The lowest fresh weight recorded for the flower head on the fifth day was obtained from the treatment with individual sucrose. Likewise, $\mathrm{Ni}$ and $\mathrm{Co}$ impede the production and accumulation of ethylene which feature an account for vase life augmentation which will positively reflect on flowers fresh weight. A gradual decrease in fresh weight was observed over the senescence period in control and treated flower, but cut spikes that were treated with $150 \mathrm{mg} / \mathrm{L}$ (SA) suppressed declining of fresh weight in early days of vase life. SA have important role in decreasing transpiration and evaporation of tissues, as well as decreasing respiration, so caused preventing from loss of fresh weight in cut flowers (Hatamzadeh et al., 2012). Calcium has presented remarkable effects in stomata closure, a mechanism that regulates water stress (Yang et al., 2003). 

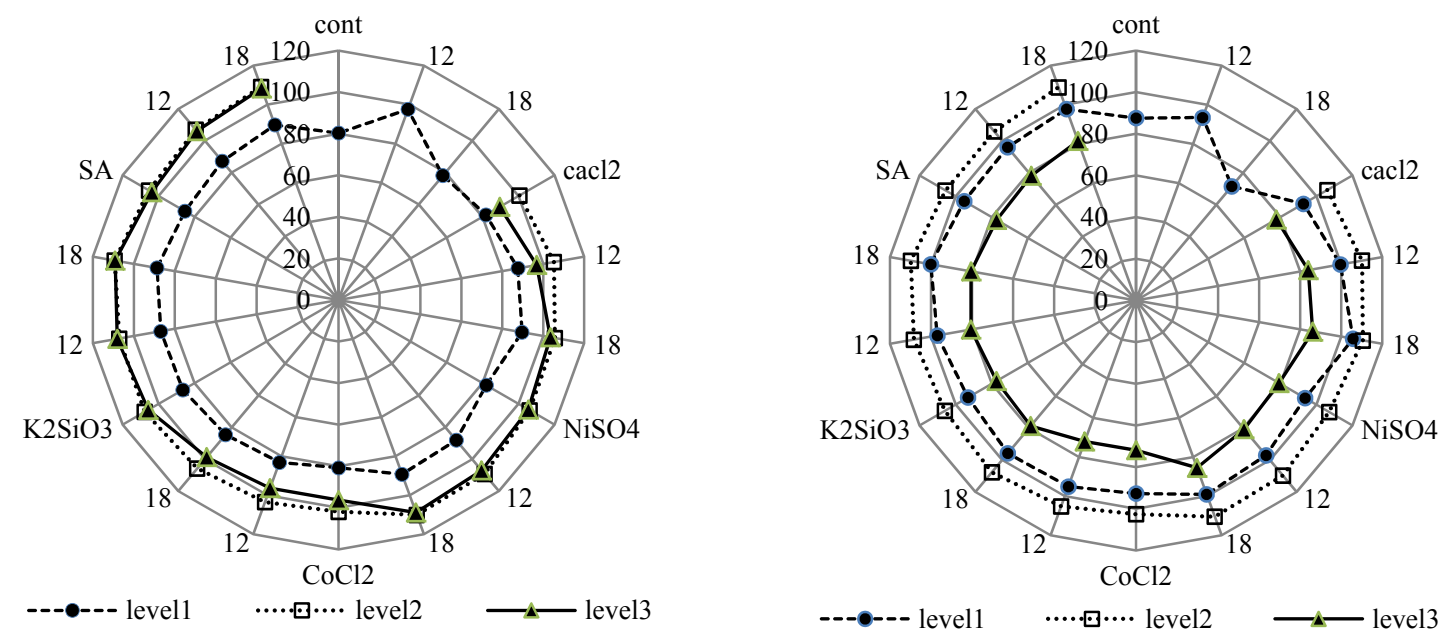

Figure 1. Effect of pre and post harvest treatments on relative flower fresh weight changes of Rudbeckia hirta, L.

(Mean of both seasons)

\subsubsection{Effect of Pre and Postharvest Treatments on Vase Life and Solution Uptake}

The highest level of pre harvest $\mathrm{CaCl}_{2}$ application flowed by $\mathrm{K}_{2} \mathrm{SiO}_{3}$ recorded absolutely longest vase life whereas $\mathrm{NiSO}_{4}$ and $\mathrm{SA}$ were secondly lies then came the others treatments (Table 3). Postharvest treatments took a completely different direction, as $\mathrm{SA}_{\text {and }} \mathrm{K}_{2} \mathrm{SiO}_{3}$ recorded the longest vase life whereas $\mathrm{CaCl}_{2}$ lies secondly. As for solution uptake, data show that pre harvest $\mathrm{CaCl}_{2}$ and $\mathrm{SA}$ application ranked firstly followed by $\mathrm{K}_{2} \mathrm{SiO}_{3}$ then the other pre harvest treatments. Only post harvest SA treatment lies firstly followed by $\mathrm{K}_{2} \mathrm{SiO}_{3}$ and $\mathrm{CaCl}_{2}$ treatments. Many researchers have confirmed this finding, Chen et al. (2004) confirmed that, holding cut Gerbera hybrida flowers in $\mathrm{CaCl}_{2}$ preservative solution resulted in extending its vase life. Bacterial population in carnation stem or vase solution which cause xylem blockage and increase ethylene production, might be greatly susceptible to $\mathrm{CaCl}_{2}$. In addition, calcium ion affect ethylene action on cell membrane by inhibiting ion leakage and reducing the effect of ethylene on senescence (Torre et al., 1999). Ichimura et al. (2001) that addition calcium chloride to the preservative solution increases the vase life, promotes flower opening. Salicylic acid can modulate plant responses to a wide range of oxidative stresses and prevents cell wall degradation (Shirasu et al., 1997). Also, Nicle and Cobalt inhibits ethylene synthesis and reduces sensitivity of flowers to ethylene. Co significantly extends carnation vase life (Jamali \& Rahemi, 2011) likewise, Kazemi (2012) reported that, cobalt significantly prolonged vase life approximately for five days over control (distilled water).

High concentrations of calcium in vegetal tissues reduce both the ethylene production and the transpiration level. Calcium may have a role as a hormone regulator in senescent tissues (Fernandes, 2002). Also, SA extended vase life in association with inhibition of ethylene production (Srivastava \& Dwivedi, 2000). The increases in water uptake and subsequently cut flower fresh weight, are apparently due to the acidifying and stress alleviating properties of SA. Salicylic acid extended vase life of cut rose flowers by regulating water uptake. Improved water balance may be due to possible germicidal activity of SA as an antimicrobial compound acting by inhibiting vascular blockage, allowing greater hydration in the flowers and/or positive regulatory role of SA on stomatal closure which regulates the rates of transpiration and increases the water retaining capacity of the petals (Lee et al., 2004; Alaey et al., 2011). 
Table 3. Effect of pre and postharvest treatments on vase life and solution uptake of Rudbeckia hirta, L. cut flower (Mean of both seasons)

\begin{tabular}{|c|c|c|c|c|c|}
\hline \multirow[b]{2}{*}{ Treatments } & \multirow[b]{2}{*}{ Level $\left(\mathrm{mg} \cdot \mathrm{L}^{-1}\right)$} & \multicolumn{2}{|c|}{ Pre-harvest treatment } & \multicolumn{2}{|c|}{ Postharvest treatment } \\
\hline & & $\begin{array}{l}\text { Vase life } \\
\text { (day) }\end{array}$ & $\begin{array}{l}\text { Solution uptake } \\
\text { (ml/3flowers) }\end{array}$ & $\begin{array}{l}\text { Vase life } \\
\text { (day) }\end{array}$ & $\begin{array}{l}\text { Solution uptake } \\
\text { (ml/3flowers) }\end{array}$ \\
\hline Control & - & 18.530 & $56.72 p$ & $23.61 \mathrm{p}$ & $62.43 p$ \\
\hline \multirow[t]{3}{*}{$\mathrm{CaCl}_{2}$} & 125 & $34.17 \mathrm{i}$ & $96.35 \mathrm{~g}$ & $28.71 \mathrm{~h}$ & $85.51 \mathrm{~g}$ \\
\hline & 250 & $38.96 b$ & $108.47 \mathrm{~d}$ & $28.96 \mathrm{~g}$ & $87.04 \mathrm{f}$ \\
\hline & 375 & $39.05 \mathrm{a}$ & $115.14 b$ & $30.44 \mathrm{f}$ & $89.84 \mathrm{e}$ \\
\hline \multirow[t]{3}{*}{$\mathrm{NiSO}_{4}$} & 30 & $33.07 \mathrm{k}$ & $84.12 \mathrm{n}$ & 27.711 & $71.66 \mathrm{~m}$ \\
\hline & 45 & $33.94 j$ & $93.55 \mathrm{i}$ & $27.15 n$ & $83.45 \mathrm{~h}$ \\
\hline & 60 & $36.61 d$ & $96.08 \mathrm{~h}$ & $28.40 \mathrm{j}$ & $79.91 \mathrm{j}$ \\
\hline \multirow[t]{3}{*}{$\mathrm{CoCl}_{2}$} & 50 & $26.35 n$ & $81.54 \mathrm{o}$ & 24.860 & $68.70 \mathrm{o}$ \\
\hline & 75 & 30.621 & 87.281 & $27.70 \mathrm{~m}$ & $70.33 n$ \\
\hline & 100 & $33.07 \mathrm{k}$ & $89.33 \mathrm{k}$ & $27.88 \mathrm{k}$ & $72.90 \mathrm{e}$ \\
\hline \multirow[t]{3}{*}{$\mathrm{K}_{2} \mathrm{SiO}_{3}$} & 100 & $28.20 \mathrm{~m}$ & $90.68 \mathrm{j}$ & $28.55 \mathrm{i}$ & $78.59 \mathrm{k}$ \\
\hline & 150 & $34.19 \mathrm{~h}$ & $105.70 \mathrm{e}$ & $31.65 \mathrm{e}$ & $82.26 \mathrm{i}$ \\
\hline & 200 & $37.06 \mathrm{c}$ & $112.93 \mathrm{c}$ & $34.82 \mathrm{c}$ & $94.60 \mathrm{c}$ \\
\hline \multirow[t]{3}{*}{$\mathrm{SA}$} & 100 & $35.01 \mathrm{~g}$ & $84.68 \mathrm{~m}$ & $33.19 \mathrm{~d}$ & $94.18 \mathrm{~d}$ \\
\hline & 150 & $35.72 \mathrm{f}$ & $97.62 \mathrm{f}$ & $37.11 \mathrm{~b}$ & $108.23 b$ \\
\hline & 200 & $36.41 \mathrm{e}$ & $118.80 \mathrm{a}$ & $37.50 \mathrm{a}$ & $115.22 \mathrm{a}$ \\
\hline
\end{tabular}

Note. Means within a column having the same letters are not significantly different in Duncan's Multiple Range Test.

\subsection{Effect of Pre and Postharvest Treatments on Flower Chemical Constituents}

In general, results showed that, flowers protein content of pre harvest treated plants was higher than those post harvest treated one (Table 4). The absolutely highest protein contents resulted from the highest level of both pre harvest application of $\mathrm{NiSO}_{4}$ followed by $\mathrm{CaCl}_{2}$ and $\mathrm{SA}$ and from post harvest application of $\mathrm{NiSO}_{4}$ followed by $\mathrm{SA}$, respectively. The other treatments recorded an intermediate protein contents compared to control. Calcium chloride delays protein and phospholipid destruction in the petal membranes and eliminates ethylene production (Torre et al., 1999). Ni has beneficial influence on rigidity of protein structures which might increase the total resistance of plants against senescence (Wood \& Reilly, 2007).

As for total soluble carbohydrates, data reveal that generally, there was an inverse relationship between treatment level and flower soluble carbohydrates contents. Pre harvest application of $\mathrm{CaCl}_{2}$ and $\mathrm{SA}$ were more effective in reducing flower soluble carbohydrates contents compared to other treatments whereas, there was no evident difference in reduction level among all post harvest treatments. Both pre and post harvest control treatment recorded the absolutely higher soluble carbohydrates contents. These findings coincides with Wood and Reilly (2007) who stated that Ni have beneficial influence on rigidity of protein structures which might increase the total resistance of plants against senescence. Lower total soluble carbohydrates is an indication on the delay in flowers senesce (Bai et al., 2006). Also, Data revel that, water sprayed treatment (control) recorded absolutely highest soluble carbohydrates during petal senescence. Some treatments lifted up total soluble carbohydrates and others were less influential (Van-Doorn \& Stead, 1997). In this respect, Faraji et al. (2011) reported that, the highest soluble carbohydrates contents of Gladioli petals was ten days after harvesting. then it began to decline exhausting the substrates. 
Table 4. Effect of pre and postharvest treatments on flower chemical constituents of Rudbeckia hirta, L. cut flower (Mean of both seasons)

\begin{tabular}{|c|c|c|c|c|c|c|c|c|c|}
\hline \multirow[t]{2}{*}{ Treatments } & \multirow[t]{2}{*}{ Level $\left(\mathrm{mg} \cdot \mathrm{L}^{-1}\right)$} & \multicolumn{2}{|c|}{$\begin{array}{l}\text { Protein contents } \\
(\mathrm{mg} / \mathrm{g} \mathrm{FW})\end{array}$} & \multicolumn{2}{|c|}{$\begin{array}{l}\text { Total soluble carbohydrates } \\
\qquad\left(\mathrm{mg} . \mathrm{g}^{-1} \mathrm{DW}\right)\end{array}$} & \multicolumn{2}{|c|}{$\begin{array}{l}\text { Anthocyanin } \\
\text { (g/100g. FW) }\end{array}$} & \multicolumn{2}{|c|}{$\begin{array}{c}\text { Total carotenoids } \\
(\mathrm{mg} / \mathrm{g} . \mathrm{FW})\end{array}$} \\
\hline & & Pre & Post & Pre & Post & Pre & Post & Pre & Post \\
\hline Control & - & $23.35 p$ & $21.13 \mathrm{o}$ & $36.56 \mathrm{a}$ & $37.68 \mathrm{a}$ & $0.07 \mathrm{j}$ & $0.09 \mathrm{~h}$ & $0.16 \mathrm{~m}$ & $0.17 \mathrm{~m}$ \\
\hline \multirow[t]{3}{*}{$\mathrm{CaCl}_{2}$} & 125 & $30.17 \mathrm{i}$ & $28.66 \mathrm{i}$ & $34.29 \mathrm{f}$ & $35.42 \mathrm{e}$ & $0.16 \mathrm{e}$ & $0.10 \mathrm{~g}$ & $0.29 \mathrm{~g}$ & $0.27 \mathrm{f}$ \\
\hline & 250 & $30.54 \mathrm{~g}$ & $29.40 f$ & $30.40 \mathrm{o}$ & 33.210 & $0.19 b$ & $0.13 \mathrm{~d}$ & $0.40 \mathrm{~b}$ & $0.33 b$ \\
\hline & 375 & $32.22 \mathrm{e}$ & $29.72 \mathrm{e}$ & $26.97 p$ & $32.19 \mathrm{p}$ & $0.20 \mathrm{a}$ & $0.15 b$ & $0.38 \mathrm{~d}$ & $0.30 \mathrm{~d}$ \\
\hline \multirow[t]{3}{*}{$\mathrm{NiSO}_{4}$} & 30 & $30.02 \mathrm{j}$ & $30.16 \mathrm{c}$ & $33.25 \mathrm{k}$ & $35.07 \mathrm{i}$ & $0.15 f$ & $0.10 \mathrm{~g}$ & $0.25 \mathrm{j}$ & $0.20 \mathrm{k}$ \\
\hline & 45 & $34.30 \mathrm{~b}$ & $32.05 \mathrm{~b}$ & 33.201 & $34.15 \mathrm{k}$ & $0.17 \mathrm{~d}$ & $0.12 \mathrm{e}$ & $0.29 \mathrm{~g}$ & $0.24 \mathrm{~h}$ \\
\hline & 60 & $36.80 \mathrm{a}$ & $33.80 \mathrm{a}$ & $33.46 \mathrm{j}$ & 34.111 & $0.18 \mathrm{c}$ & $0.12 \mathrm{e}$ & $0.36 \mathrm{e}$ & $0.31 \mathrm{c}$ \\
\hline \multirow[t]{3}{*}{$\mathrm{CoCl}_{2}$} & 50 & $27.21 \mathrm{n}$ & $26.65 \mathrm{~m}$ & $36.30 \mathrm{~b}$ & $36.20 \mathrm{~b}$ & $0.10 \mathrm{i}$ & $0.09 \mathrm{~h}$ & 0.191 & $0.15 n$ \\
\hline & 75 & $27.50 \mathrm{~m}$ & 26.951 & $35.19 \mathrm{~d}$ & $35.33 \mathrm{f}$ & $0.13 \mathrm{~h}$ & $0.11 \mathrm{f}$ & $0.23 \mathrm{k}$ & 0.181 \\
\hline & 100 & 27.831 & $27.02 \mathrm{kl}$ & $33.55 \mathrm{i}$ & $34.90 \mathrm{j}$ & $0.15 \mathrm{f}$ & $0.11 \mathrm{f}$ & $0.27 \mathrm{~h}$ & $0.21 \mathrm{j}$ \\
\hline \multirow[t]{3}{*}{$\mathrm{K}_{2} \mathrm{SiO}_{3}$} & 100 & $29.66 \mathrm{k}$ & $27.08 \mathrm{k}$ & $35.72 \mathrm{c}$ & $36.02 \mathrm{c}$ & $0.13 \mathrm{~h}$ & $0.10 \mathrm{~g}$ & $0.26 \mathrm{i}$ & $0.22 \mathrm{i}$ \\
\hline & 150 & $31.07 \mathrm{f}$ & $29.11 \mathrm{~g}$ & $34.22 \mathrm{~g}$ & $35.16 \mathrm{~g}$ & $0.16 \mathrm{e}$ & $0.13 \mathrm{~d}$ & $0.35 \mathrm{f}$ & $0.29 \mathrm{e}$ \\
\hline & 200 & $30.42 \mathrm{~h}$ & $29.00 \mathrm{~h}$ & $34.19 \mathrm{~h}$ & $35.08 \mathrm{~h}$ & $0.19 b$ & $0.15 b$ & $0.39 \mathrm{c}$ & $0.33 b$ \\
\hline \multirow[t]{3}{*}{$\mathrm{SA}$} & 100 & 24.630 & $24.50 \mathrm{~m}$ & $34.84 \mathrm{e}$ & $35.77 d$ & $0.14 \mathrm{~g}$ & $0.12 \mathrm{e}$ & $0.25 \mathrm{j}$ & $0.25 \mathrm{~g}$ \\
\hline & 150 & $33.08 \mathrm{~d}$ & $28.33 \mathrm{j}$ & $32.77 \mathrm{~m}$ & $34.04 \mathrm{~m}$ & $0.15 f$ & $0.14 \mathrm{c}$ & $0.36 \mathrm{e}$ & $0.31 \mathrm{c}$ \\
\hline & 200 & $33.50 \mathrm{c}$ & $30.06 \mathrm{~d}$ & $31.79 n$ & $33.62 n$ & $0.18 \mathrm{c}$ & $0.18 \mathrm{a}$ & $0.44 \mathrm{a}$ & $0.35 \mathrm{a}$ \\
\hline
\end{tabular}

Note. Means within a column having the same letters are not significantly different in Duncan's Multiple Range Test.

Anthocyanin content in flowers was increased in response to all treatments comparing with control while, the mastery was attributed to pre harvest $\mathrm{CaCl}_{2}$ and $\mathrm{K}_{2} \mathrm{SiO}_{3}$ treatments and postharvest salicylic acid treatment. In the second rank lie pre harvest $\mathrm{NiSO}_{4}$ and salicylic acid and postharvest $\mathrm{CaCl}_{2}$ and $\mathrm{K}_{2} \mathrm{SiO}_{3}$ treatments. The highest carotene contents recorded with pre or postharvest SA treatment followed by the medium level of $\mathrm{CaCl}_{2}$ then came all the other treatments. In this respect, Salicylic acid in holding solution significantly decreased anthocyanin leakage in carnation cut flowers (Kazemi et al., 2011). Also, Kazemi (2012) reported that, cobalt significantly decreased anthocyanin leakage. Moharekar et al. (2003) reported that salicylic acid activated the synthesis of carotenoids and xanthophylls. Ayad (2010) reported that, the higher level of $\mathrm{CaCl} 2$ caused a significant reductions in carotenoids contents up to $45 \%$. Likewise, Sharma and Hall (1991) concluded that, the decrease in carotenoids with increasing $\mathrm{CaCl}_{2}$ level lead to the degradation of $\beta$-carotene and formation of zeaxanthins, which are apparently involved in protection against photo inhibition.

\section{Conclusion}

High level Pre-harvest sprayed plants with $\mathrm{CaCl}_{2}$ or postharvest holding flowers with SA recorded the absolutely tallest flowers vase life. generally, preharvest treatment especially with $\mathrm{CaCl}_{2}, \mathrm{~K}_{2} \mathrm{SiO}_{3}$ or $\mathrm{SA}$ was more impact and effective in improving both Rudbeckia hirta, L. plant or flowers characters than postharvest treatment.

\section{References}

Alaey, M., Babalar, M., Naderi, R., \& Kafi, M. (2011). Effect of pre and postharvest salicylic acid treatment on physio-chemical attributes in relation to vase life of rose cut flowers. Postharvest Biol. and Techno., 61, 91-94. http://dx.doi.org/10.1016/j.postharvbio.2011.02.002

Ayad, J. Y. (2010). Comparative effects of $\mathrm{CaCl}_{2}$ and $\mathrm{NaCl}$ salinity on growth and ion partitioning of Atriplex halimus L. Dirasat, Agric. Sci., 37(2), 82-90.

Bai, C., Reilly, C. C., \& Wood, B. W. (2006). Nickel deficiency disrupts metabolism of ureides and amino acids of young pecan foliage. Plant Physiol., 140, 433-443. http://dx.doi.org/10.1104/pp.105.072983

Bleeksma, H. C., \& Van Doorn, W. G. (2003). Embolism in rose stems as a result of vascular occlusion by bacteria. Postharvest Biol. and Techno., 29, 334-340. http://dx.doi.org/10.1016/s0925-5214(03)00049-8 
Bradford, M. (1976). A rapid and sensitive method for quantiation of microgram quantities of protein utilizing the principle of protein - dye binding. Anal. Biochem., 72, 248-252. http://dx.doi.org/10.1016/0003-2697 (76)90527-3

Brown, P. H., Welch, R. M., \& Carry, E. E. (1987). Nickel: A micronutrient essential for higher plants. Plant Physiol., 85, 801-803. http://dx.doi.org/10.1104/pp.85.3.801

Capdeville, G. D., Maffia, L. A., Finger, F., \& Batista, U. G. (2005). Pre-harvest calcium sulfate applications affect vase life and severity of gray mold in cut roses. Sci. Hort., 103, 329-338. http://dx.doi.org/10.1016/j. scienta.2004.06.016

Chamani, A. K., Joyce, D. C., Irvin, D. E., Zamani, Z. A., Mostofi, Y., \& Kafi, M. (2005). Ethylene and anti-ethylene treatment effects on cut 'First Red' rose. J. Appl. Hort., 1, 3-7.

Cortes, M. H., Frias, A. A., Moreno, S. G., Pina, M. M., De La Cruz Guzman, G. H., \& Sandoval, S. G. (2011). The Effects of calcium on postharvest water status and vase life of Rosa hybrida cv. Grand Gala. Int. J. Agric. Biol., 13(2), 233-238.

Duncan, D. B. (1955). Multiple range and multiple F test. Biometrics., 11, 1-42. http://dx.doi.org/10.2307/ 3001478

Faraji, S., Naderi, R., Ibadli, O. V., Basaki, T., Gasimov, S. N., \& Hosseinova, S. (2011). Effects of post harvesting on biochemical changes in Gladiolus cut flowers cultivars [White prosperity]. Middle-East J. Sci Res., 9(5), 572-577.

Ferguson, I. B. (1984). Calcium in plant senescence and fruit ripening. Plant Cell Environ., 7, 77-489. http://dx.doi.org/10.1111/j.1365-3040.1984.tb01438.x

Fernandes, R. R. (2002). Fisiologia pós-colheita de espécies olerícolas. In C. M. Wachowicz \& R. I. N. Carvalho (Eds.), Fisiologia vegetal: produção e pós-colheita (pp. 315-358). Curitiba: Champagnat.

Fulcher, A., Dunwell, W. C., \& Wolfe, D. (2003). Rudbeckia taxa evaluation. SNA Res. Conf., 48, 510-512.

Gilman, F. G., \& Howe, T. (1999). Rudbeckia hirta Black-Eyed Susan, Gloriosa Daisy. Research Programs/Services, Gulf Coast Research and Education Center; UF/IFAS Extension, Gainesville, FL 32611. The Institute of Food and Agricultural Sciences (IFAS). Retrieved from http:/edis.ifas.ufl.edu

Hatamzadeh, A., Hatami, M., \& Ghasemnezhad, M. (2012). Efficiency of salicylic acid delay petal senescence and extended quality of cut spikes of Gladiolus grandiflora cv 'wing's sensation'. Afr. J. Agric. Res., 7(4), 540-545.

Husia, C. L., Luh, B. S., \& Chichester, C. D. (1965). Anthocyanin in free stone peaches. J. Food Sci., $30,5-12$. http://dx.doi.org/10.1111/j.1365-2621.1965.tb00253.x

Ichimura, K., Kawabata, Y., Kishimoto, M., Goto, R., \& Yamada, K. (2001). Variation with the cultivar in the vase life of cut rose flowers. Bull. Natu. Inst. Floricult. Sci., 2, 9-20.

Jamali, B., \& Rahemi, M. (2011). Carnation flowers senescence as influenced by nickel, cobalt and silicon. $J$. Biol. Environ. Sci., 5, 147-152.

Jamshidi, M., Hadavi, E., \& Naderi, R. (2012). Effects of salicylic acid and malic acid on vase life and bacterial and yeast populations of preservative solution in cut Gerbera flowers. Inter. J. of Agric. Sci., 2(8), 671-674.

Joyce, D. C., \& Jones, P. N. (1992). Water balance of the foliage of cut Geraldton wax flower. J. Postharvest Biol. Technol., 2, 31-39. http://dx.doi.org/10.1016/0925-5214(92)90025-K

Kazemi, M. (2012). Effect of cobalt, silicon, acetyl salicylic acid and sucrose as novel agents to improve vase life of Argyranthemum flowers. Trends Applied Sci. Res., 7(7), 579-583. http://dx.doi.org/10.3923/tasr. 2012.579.583

Kazemi, M., Hadavi, E., \& Hekmati, J. (2011). Role of salicylic acid in decreases of membrane senescence in cut carnation flowers. Amer. J. of Plant Physiol., 6(2), 106-112. http://dx.doi.org/10.3923/ajpp.2011.106.112

Khan, W., Prithiviraj, B., \& Smith, D. L. (2003). Photosynthetic response of corn and soybean to foliar application of salicylates. J. Plant Physiol., 160, 492-485. http://dx.doi.org/10.1078/0176-1617-00865

Leslie, C. A., \& Romani, R. J. (1988). Inhibition of ethylene biosynthesis by salicylic acid. Plant Physiol., 88, 833-837. http://dx.doi.org/10.1104/pp.88.3.833 
Malakooti, M. J. (2001). Why calcium spray in fruit trees should be common (pp. 273-283). Jahad Keshavarsy Embassy. Hort. section.

Michalczuk, B., Goszczynska, D. M., Rudnicki, R. M., \& Halevy, A. H. (1989). Calcium promotes longevity and bud opening in cut rose flowers. Isr. J. Bot., 38, 209-215.

Moharekar, S. T., Lokhande, S. D., Hara, T., Tanaka, R., Tanaka, A., \& Chavan, P. D. (2003). Effect of salicylic acid on clorophyll and carotenoid contents of wheat and Moong caryopsis. Photosynthetica, 41, 315-317. http://dx.doi.org/10.1023/B:PHOT.0000011970.62172.15

Morris, K., Mackerness, S. A. H., Page, T., John, C. F., Murphy, A. M., Carr, J. P., \& Buchanan-Wollaston, V. (2000). Salicylic acid has a role in regulating gene expression during leaf senescence. Plant J., 23, 677-685. http://dx.doi.org/10.1046/j.1365-313x.2000.00836.x

Mortazavi, N., Naderi, R., Khalighi, A., Balabar, M., \& Allizadeh, H. (2007). The effect of cytokinin and calcium on cut flowers quality in rose (Rosa hybrida L.) cv. Iliona. J. Food Agric. Environ., 5, 311-313.

MSTAT Development Team. (1989). Mstat User's Guide: A microcomputer program for the design management and analysis research experiments. Michigan State Univ. East Lansing, USA.

Nornai, R. (1982). Formula for determination of chlorophyllus pigments extracted with N.N-dimethyl formamide. Plant Physiol., 69, 1376-1381. http://dx.doi.org/10.1104/pp.69.6.1376

Paquan, R., \& Lechasseur, P. (1976). Observations on the free proline assay in extracts of plants. Can. J. BOT., $57,1851-1854$.

Poovaiah, B. W. (1979). Increased levels of calcium in the nutrient solution improves the postharvest life of potted roses. J. Amr. Soc. Hort. Sci., 104, 164-166.

Raskin, I. (1992). Salicylate, a New Plant Hormone. Plant Physiol., 99, 799-803. http://dx.doi.org/10.1104/ pp.99.3.799

Renault, S. (2005). Response of red-osier dogwood (Cornus stolonifera) seedlings to sodium sulphate salinity: Effects of supplemental calcium. Pysiol. Plant., 123, 75-81. http://dx.doi.org/10.1111/j.1399-3054. 2005.00444.x

Sharma, P. K., \& Hall, D. O. (1991). Interaction of salt stress and photo inhibition on photosynthesis in barley and sorghum. J. Plant Physiol., 138, 614-619. http://dx.doi.org/10.1016/S0176-1617(11)80251-8

Shirasu, K., Nakajima, A., Rajshekar, K., Dixon, R. A., \& Lamb, C. (1997). Salicylic acid potentiates an agonist-dependent gain control. That amplifies pathogen signal in the activation of defense mechanism. Plant Cell, 9, 261-270. http://dx.doi.org/10.1105/tpc.9.2.261

Smith, N. G., \& Woodburn, J. (1984). Nickel and ethylene involvement in the senescence of leaves and flowers. Z Natur Wiss, 71(4), 210-211. http://dx.doi.org/10.1007/BF00490435

Snyder, G. H., Martichenkov, V. V., \& Datnoff, L. E. (2007). Silicone. In A. V. Barker \& D. J. Pilbean (Eds.), Handbook of Plant Nutrition (pp. 551-568). CRC Taylor and Francis, New York, USA.

Srivastava, M. K., \& Dwivedi, U. N. (2000). Delayed ripening of banana fruit by salicylic acid. Plant Sci., 158, 87-96. http://dx.doi.org/10.1016/S0168-9452(00)00304-6

Talukder, G., \& Sharma, A. (2007). Cobalt. In A. V. Barker \& D. J. Pilbean (Eds.), Handbook of Plant Nutrition (pp. 499-514). CRC Taylor and Francis, New York, USA.

Torre, S., Borochov, A., \& Halevy, A. H. (1999). Calcium regulation of senescence in rose. Physiol. Plantarum., 107, 214-219. http://dx.doi.org/10.1034/j.1399-3054.1999.100209.x

Tosh, S., Choudhuri, M. A., \& Chatterjee, S. K. (1979). Retardation of lettuce leaf senescence by cobalt ions. Indian J. Exp. Biol., 17, 1134-1136.

Van Doorn, W. G., Zagory, D., Witte, Y. D., \& Harkema, H. (1994). Effect of vase-water bacteria on the senescence of cut carnation flowers. Postharvest Biol. Technol., 1, 161-168. http://dx.doi.org/10.1016/0925 $-5214(91) 90008-Y$

Van-Doorn, W. G., \& Stead, A. D. (1997). The physiology of petal senescence which is not initiated by ethylene. In R. J. Scott \& A. D. Stead (Eds.), Molecular and cellular aspects of plant reproduction (pp. 239-254). Cambridge University Press, Cambridge, UK. 
Wood, B. W., \& Reilly, C. C. (2007). Nickel and plant disease. In L. E. Datnoff, W. H. Elmber \& D. M. Huber (Eds.), Mineral Nutrition and Plant Diseases (pp. 351-402). APS Press, Minneapolis, USA.

Yang, H. M., Zhang, X. Y., Wang, G. X., Li, Y., \& Wei, X. P. (2003). Cytosolic calcium oscillation may induce stomatal oscillation in Vicia faba. Plant Sci., 65, 1117-1122. http://dx.doi.org/10.1016/S0168-9452(03) 00319-4

Zencirkiran, M. (2005). Effect of sucrose and silver thiosulphate pulsing on stem-base cracking and vase life in Leucojum aestivum L. Flowers. J. of Hort. Sci. and Biotech., 80(3), 332-334.

Zencirkiran, M. (2010). Effect of 1-MCP (1- Methyl Cyclopropene) and STS (Silver thiosulphate) on the vase life of cut Freesia flowers. Sci. Res. Essay., 5(17), 2409-2412.

\section{Copyrights}

Copyright for this article is retained by the author(s), with first publication rights granted to the journal.

This is an open-access article distributed under the terms and conditions of the Creative Commons Attribution license (http://creativecommons.org/licenses/by/4.0/). 